\title{
PENGARUH KUALITAS JASA TERHADAP KEPERCAYAAN DAN KEPUASAN PADA TOURIST INFORMATION CENTRE SURABAYA
}

\author{
Kurnia Maharani Putri' ${ }^{1}$ I Wayan Suardana ${ }^{2}$, Ni Putu Eka Mahadewi ${ }^{3}$ \\ 1Email: niamhrn15@gmail.com \\ Program Studi Industri Perjalanan Wisata Fakultas Pariwisata, Universitas Udayana \\ 2Email: suardana_ipw@unud.ac.id \\ Program Studi Industri Perjalanan Wisata Fakultas Pariwisata, Universitas Udayana \\ 3Email: eka.mahadewi23@gmail.com \\ Program Studi Industri Perjalanan Wisata Fakultas Pariwisata, Universitas Udayana
}

\begin{abstract}
Tourist Information Centre is one of the important tourism supporting facilities in a tourist destination precisely in the city of Surabaya. The purpose of this study to determine the effect of service quality from the Tourist Information Center to the trust and satisfaction of tourists who visit. This research was conducted at the Tourist Information Center of Surabaya City. Types of data used are qualitative and quantitative data, data collection using questionnaire method, interview and observation. Determination of sample is done by purposive sampling whereas sampling method using representative method of number of indicator multiplied 5 until 10 with get result of 180 tourist. The collected data were analyzed by path analysis method using PLS.The result of the research shows that service quality has significant effect to trust havin gprobability value $<0,05$, service quality have significant influence to satisfaction with probability value $<0,05$ and trust have significant effect to satisfaction with probability value $<0,05$. It states that all hypotheses are accepted. The trust variable proves to be an intervening of 0.6873 which means that variable increasing trust will be a good bridge to the relationship between service quality and satisfaction. The suggestion to increase Tourist Information Center in order to facilitate the access of tourists in obtaining in formation about tourism. And more to place the location to be easily known by tourists.
\end{abstract}

Abstrak : Tourist Information Centre adalah salah satu fasilitas penunjang pariwisata yang cukup penting dalam sebuah destinasi wisata tepatnya di Kota Surabaya. Tujuan penelitian ini untuk mengetahui pengaruh kualitas jasa dari Tourist Information Centre terhadap kepercayaan dan kepuasan wisatawan yang berkunjung. Penelitian ini dilaksanakan di Tourist Information Centre Kota Surabaya. Jenis data yang digunakan adalah data kualitatif dan kuantitatif, pengumpulan data menggunakan metode kuesioner, wawancara serta observasi. Penentuan sampel dilakukan dengan purposive sampling sedangkan pengambilan sampel menggunakan metode representatif jumlah indikator dikali 5 hingga 10 dengan mendapatkan hasil 180 wisatawan. Data yang terkumpul dianalisis dengan metode analisis jalur menggunakan PLS. Hasil penelitian menunjukan bahwa kualitas jasa berpengaruh signifikan terhadap kepercayaan memiliki nilai probabilitas $<0,05$, kualitas jasa berpengaruh signifikan terhadap kepuasan dengan nilai probabilitas $<0,05$ serta kepercayaan berpengaruh signifikan terhadap kepuasan dengan nilai probabilitas $<0,05$. Hal ini menyatakan bahwa semua hipotesis diterima. Variabel kepercayaan terbukti sebagai variabel intervening sebesar 0,6873 yang berarti bahwa semakin meningkatnya kepercayaan akan menjadi jembatan yang baik bagi hubungan antara kualitas jasa dengan kepuasan. Adapun saran untuk memperbanyak Tourist Information Centre agar mempermudah akses wisatawan dalam memperoleh informasi seputar kepariwisataan. Serta lebih menempatkan lokasi agar mudah diketahui oleh wisatawan.

Keywords : service quality, trust, satisfaction, tourist information centre. 


\section{PENDAHULUAN}

Pariwisata adalah sektor yang sangat penting karena salah satu penyumbang devisa yang cukup besar bagi Indonesia. Oleh karena itu, Kementrian Pariwisata dan Ekonomi Kreatif sedang berusaha untuk meningkatkan jumlah kunjungan wisatawan mancanegara untuk berwisata ke Indonesia. Dalam meningkatkan kunjungan wisatawan terhadap suatu daerah, perlunya kerjasama antara pihak pemerintah dengan pihak-pihak terkait kepariwisataan sangat penting. Dalam hal ini, berbagai upaya dilakukan pemerintah agar kunjungan wisatawan semakin meningkat. Seperti melakukan promosi besar-besaran, melakukan branding, memperbaiki daya tarik wisata di daerah tersebut. Kerjasama dilakukan oleh beberapa pihak seperti jasa perjalanan wisata, pengelola destinasi wisata serta masyarakat daerah terus dilakukan agar supaya berkesinambungan dalam meningkatkan pariwisata di suatu daerah.

Surabaya adalah salah satu destinasi tujuan wisata yang sangat berpotensiat menyedot wisatawan mancanegara maupun nusantara. Kementrian Pariwisata menyebutkan bahwa Kota Surabaya menjadi bagian dari 10 peringkat tertinggi indeks pariwisata di Indonesia yang menempati urutan kedua. Penyusunan ranking tersebut didapat melalui survey dan mengacu pada Travel and Tourism Competitiveness Index (TTCI) yang dikeluarkan World Economic Forum (WEF) yang disesuaikan dengan kondisi di Indonesia.. Tersedianya sarana dan parasarana pariwisata erat kaitannya dengan kebutuhan wisatawan di suatu destinasi wisata yang perlu diperhatikan pihak-pihak keparwisataan agar wisatawan tersebut merasa nyaman dan ingin kembali lagi untuk menikmati daya tarik wisata di suatu daerah. Menurut Yoeti (1992), sarana wisata dapat dibagi menjadi tiga unsur pokok, diantaranya :

1) Sarana pokok pariwisata, adalah perusahaan yang hidup dan kehidupannya tergantung pada arus kedatangan orang yang melakukan perjalanan wisata. Termasuk dalam kelompok ini adalah travel agent, perusahaanperusahaan angkutan wisata, serta jenis akomodasi lainnya, restoran dan rumah makan lainnya serta obyek wisata dan atraksi wisata.
2) Sarana pelengkap kepariwisataan adalah perusahaan atau tempat yang menyediakan fasilitas untuk rekreasi yang fungsinya tidak hanya melengkapi sarana pokok kepariwisataan, tetapi yang terpenting adalah menjadikan para wisatawan lebih lama tinggal pada suatu daerah tujuan wisata. 3) Sarana penunjang kepariwisataan adalah perusahaan yang menunjang sarana pelengkap dan sarana pokok dan berfungsi tidak hanya membuat para wisatawan betah pada suatu daerah tujuan wisata tetapi fungsi yang lebih penting adalah agar wisatawan lebih banyak mengeluarkan atau membelanjakan uangnya di tempat yang dikunjunginya. Seiring meningkatnya pertumbuhan ekonomi dan kesejahteraan masyarakat, kebutuhan untuk berlibur pun semakin meningkat sehingga diperlukan suatu informasi tentang tujuan wisata, obyek wisata yang menarik, sarana yang tersedia seperti transportasi, produk wisata dan sebagainya. Namun demikian seringkali wisatawan atau calon wisatawan baik lokal maupun mancanegara mengalami kesulitan untuk memperoleh informasi tersebut karena tidak mengetahui di mana dan dari siapa informasi bisa didapatkan. Oleh karena itu informasi di bidang pariwisata perlu disiapkan dengan baik dan terstruktur agar publik dapat mengakses dengan mudah dan efisien demi mengimbangi semakin modernnya zaman.

Tourist Information Centre atau yang lebih dikenal dengan TIC, memiliki peran dalam memberikan informasi seputar kepariwisataan kepada wisatawan sesuai kebutuhannya. Jasa penyedia informasi ini diharapkan ada di setiap daerah/kota yang memiliki daya tarik wisata sehingga dapat memudahkan wisatawan dalam mencari informasi mengenai destinasi tujuan wisata yang dikunjungi oleh wisatawan. Seperti halnya kota-kota besar lainnya, Kota Surabaya yang tak luput dalam menyediakan Tourist Information Centre bagi wisatawan yang berkunjung dalam mencari informasi seputar kepariwisataan.

Sesuai dengan Undang-Undang Nomor 10 Tahun 2009 tentang Kepariwisataan pasal $20 \mathrm{~A}$ yang menyatakan setiap wisatawan berhak mendapatkan informasi yang akurat mengenai daya tarik wisata dan Peraturan Daerah Kota Surabaya Nomor 23 Tahun 2012 Pasal 2F menyatakan salah satu kewenangan pemerintah daerah dalam membangun industri pariwisata adalah memfasilitasi dan 
melakukan promosi destinasi pariwisata dan produk pariwisata yang berada di daerah. Sejak tahun 2013, pemerintah Kota Surabaya mengadakan fasilitas penunjang kepariwisataan yang disebut Tourist Information Centre. Kota Surabaya hanya memiliki 1 Tourist Information Centre yang masih berdiri sampai sekarang. Namun keberadaan Tourist Information Centre ini masih tidak banyak diketahui oleh wisatawan. Selain itu dengan arus perkembangan teknologi, wisatawan lebih memilih mengakses informasi melalui internet daripada mengunjungi Tourist Information Centre. Dalam upayanya, Tourist Information Centre Kota Surabaya juga telah membuat akun di media sosial dalam memudahkan wisatawan memperoleh informasi.Cukup banyak wisatawan yang mengunjungi Tourist Information Centre ini untuk memperoleh informasi seputar kepariwisataan yang terlihat pada jumlah kunjungan pada Tabel 1.

Tabel 1. Kunjungan Wisatawan ke Tourist Information Centre di Kota Surabaya Tahun 2012-2016

\begin{tabular}{rrrr}
\hline No & Tahun & $\begin{array}{c}\text { Jumlah } \\
\text { Pengunjung }\end{array}$ & $\begin{array}{r}\text { Pertumbuhan } \\
(\%)\end{array}$ \\
1 & 2012 & 5604 & - \\
2 & 2013 & 5865 & 4,65 \\
3 & 2014 & 4354 & -25 \\
4 & 2015 & 3203 & -26 \\
5 & 2016 & 2958 & $-7,6$ \\
\multicolumn{2}{c}{ TOTAL } & 21984 & $-53,95$ \\
\hline
\end{tabular}

Sumber : Tourist Information Centre Kota Surabaya, 2017

Berdasarkan jumlah kunjungan pada Tabel 1, terlihat penurunan jumlah pengunjung yang terjadi di setiap tahunnya. Pada tahun 2013 terdapat peningkatan jumlah pengunjung dikarenakan masih barunya didirikan Tourist Information Centre sehingga wisatawan penasaran dan ingin berkunjung. Pada tahun 2014 terdapat penurunan sebesar $-25 \%$, hal ini kemungkinan internet sudah mulai memasuki ranah masyarakat dalam mencari informasi. Selain itu, terjadi pemindahan lokasi kantor Tourist Information Centre yang semula di depan, dipindah ke belakang. Pada tahun 2015 terlihat penurunan pengunjung meningkat menjadi $-26 \%$. Hal ini juga dipicu dengan adanya Erupsi Gunung Bromo yang mempengaruhi jumlah kunjungan wisatawan di Surabaya. Tak hanya Surabaya, Bali juga menjadi dampak akibat terjadinya bencana alam tersebut sehingga akses penerbangan banyak yang ditutup. Pada tahun 2016, penurunan jumlah pengunjung cukup berkurang dikarenakan telah adanya perbaikan maupun telah diadakannya promosi untuk menekan penurunan jumlah kunjungan. Selain itu, Tourist Information Centre juga telah menyediakan website maupun media sosial untuk lebih mudah diakses oleh wisatawan. Selain itu, lokasi yang kurang cukup terlihat oleh wisatawan sehingga tidak mengetahui secara jelas di mana Tourist Information Centre berada.

Selain berdasarkan penyebab penurunan jumlah pengunjung tersebut di atas, kegiatan jasa tidaklah terlepas dari produsen dan konsumen itu sendiri. Dalam hal ini, penyedia jasa informasi pariwisata memberikan jasa yang dapat memenuhi kebutuhannya. Wisatawan sebagai konsumen diharapkan mendapatkan suatu kepercayaan serta kepuasan dalam memenuhi kebutuhannya. Hal ini erat kaitannya dengakualitas jasa / kualitas pelayanan yang diberikan oleh Tourist Information Centre tersebut. Penurunan kunjungan bisa terjadi oleh banyak hal, maka perlunya diketahui penyebab menurunnya jumlah kunjungan pada Tourist Information Centre. Penelitian ini dinilai perlu sebagai bahan evaluasi Pemerintah Kota Surabaya khususnya untuk Dinas Kebudayaan dan Pariwisata Kota Surabaya dalam memperbaiki kualitas maupun sebagai bahan evaluasi untuk meningkatkan jumlah kunjungan pada Tourist Information Centre. Dalam hal ini, rumusan masalah yang diambil yaitu bagaimana pengaruh kualitas jasa terhadap kepercayaan, bagaimana pengaruh kualitas jasa terhadap kepuasan, serta bagaimana pengaruh kualitas jasa terhadap kepuasan melalui kepercayaan. Tujuan yang dicapai adalah hasil dari semua rumusan masalah yang akan menjawab ada atau tidaknya pengaruh pada setiap variabel.

Adapun karya ilmiah terdahulu yang menjadi landasan ataupun acuan dibuatnya jurnal ini agar menjadi penelitian yang mendukung hasil dari jurnal yaitu seperti di bawah ini:

Babatunde A. Popoola, Richard Chinomona, Elizabeth Chinomona (2014) meneliti tentang "The Influence of Information Quality, System Qualityand Service Quality on Student's Self-Efficacy at Institutions of 
Higher Learning in South Africa. Penelitian tersebut berisi tentang bagaimana pengaruh kualitas informasi, kualitas sistem dan kualitas pelayanan pada kemampuan diri siswa di lembaga pendidikan tinggi di Afrika Selatan. Dan hasilnya membuktikan adanya pengaruh positif dari beberapa variabel di atas dalam mempengaruhi kemampuan diri pada mahasiswa. Persamaan terlihat pada variabelserta indikator kualitas pelayanan yang sama dengan penelitian ini. Selain itu perbedaan terlihat pada teknik analisis data yang digunakan dan variabel yang tidak digunakan oleh peneliti.

Mukhles Al-Ababneh (2013) meneliti tentang Service Quality and its Impacton Tourist Satisfaction yang berisi tentang pengaruh kualitas pelayanan jasa terhadap kepuasan wisatawan pada sebuah destinasi wisata. Beberapa hal yang menjadi tolak ukur dalam kualitas pelayanan jasa yaitu fasilitas, atraksi dan akses yang kemudian diuji menggunakan analisis linier berganda. Hasil dari penelitian tersebut yaitu adanya pengaruh yang signifikan pada kepuasan wisatawan yang dipengaruhi oleh kualitas jasa. Semakin tinggi kualitas jasa, kepuasan akan semakin meningkat. Persamaan penelitian tersebut dengan penelitian ini terlihat pada kesamaan variabel yaitu kualitas jasa yang mempengaruhi kepuasan wisatawan. Namun perbedaan juga terdapat pada objek yang diteliti lebih mengarah kepada destinasi wisata.

I Gede Yogi Pramana dan Ni Made Rastini (2016) meneliti tentang Pengaruh Kualitas Pelayanan Terhadap Kepercayaan Nasabah dan Loyalitas Nasabah Bank Mandiri. Penelitian ini dilakukan untuk mengetahui pengaruh kualitas pelayanan terhadap kepercayaan dan loyalitas nasabah Bank Mandiri. Menggunakan teknik sampel yang sama yaitu purposive sampling dengan jumlah responden 150 orang. Hasil dari penelitian tersebut yakni kualitas pelayanan berpengaruh signifikan terhadap kepercayaan serta loyalitas nasabah. Persamaan banyak terlihat dengan penelitian ini terlihat pada teknik sampling serta teknik analisis yang digunakan yaitu analisis jalur yang memiliki kerangka pemikiran yang sama. Perbedaan hanya terlihat pada variabel yang menggunakan loyalitas, bukan kepuasan.

Arieaman Hermanoe (2010) telah meneliti tentang Analisis Pengaruh Kualitas
Layanan, Kepercayaan Dan Kepuasan Terhadap Loyalitas Pelanggan Pada PT. Kharisma Gamaba Jaya Surabaya. Penelitian tersebut memiliki tujuan untuk mengetahui adakah pengaruh di antara variabel-variabel di atas. Menggunakan analisis SEM yang menggunakan sampel 100 perusahaan. Hasil yang didapat dari penelitian tersebut mengatakan bahwa kualitas pelayanan tidak berpengaruh signifikan terhadap kepercayaan. Sedangkan kualitas layanan dan kepuasan berpengaruh signifikan terhadap loyalitas pelanggan. Persamaan bisa dilihat pada teknik analisis. Analisis SEM adalah lanjutan dari analisis jalur sehingga terdapat bagian-bagian yang sama dengan penelitian ini. Perbedaan terlihat pada hasil yang didapat setelah dilakukan uji hipotesis serta adanya variabel loyalitas pelanggan.

Selain beberapa penelitian terdahulu di atas, terdapat beberapa teori yang digunakan penulis sebagai acuan dalam melakukan penelitian ini yaitu:

Parasuramanetal

mengidentifikasi dimensi kualitas jasa menjadi 5 yaitu: 1) Reliabilitas (reability), berkaitan dengan kemampuan perusahaan untuk memberikan layanan yang akurat sejak pertama kali tanpa membuat kesalahan apapun dan menyampaikan jasanya sesuai dengan waktu yang disepakati. 2) Daya tanggap (responssiveness), berkenaan dengan kesediaan dan kemampuan para karyawan untuk membantu para pelanggan dan merespons permintaan mereka, serta menginformasikan kapan jasa akan diberikan dan kemudian memberikan jasa secara cepat. 3) Jaminan (assurance), yakni perilaku para karyawan mampu menumbuhkan kepercayaan pelanggan terhadap perusahaan dan perusahaan bias menciptakan rasa aman bagi para pelanggannya. Jaminan juga berarti bahwa para karyawan selalu bersikap sopan dan menguasai pengetahuan dan keterampilan yang dibutuhkan untuk menangani setiap pertanyaan atau masalah pelanggan. 4) Empati (empathy), berarti perusahaan memahami masalah para pelanggannya dan bertindak demi kepentingan pelanggan, serta memberikan perhatian personal kepada para pelanggan dan memiliki jam operasi yang nyaman. 5) Bukti fisik (tangibles), berkenaan dengan daya tarik fasilitas fisik, perlengkapan, dan material yang digunakan perusahaan, serta penampilan karyawan. 
Menurut $\mathrm{Ba}$ dan Pavlou (2002) mendefinisikan kepercayaan sebagai penilaian hubungan seseorang dengan orang lain yang akan melakukan transaksi tertentu sesuai dengan harapan dalam sebuah lingkungan yang penuh ketidakpastian. Jasfar (2009:169) menyatakan bahwa indikator kepercayaan terdiri dari 3 komponen, yaitu: (1) persepsi integritas (Integrity), merupakan persepsi konsumen bahwa perusahaan mengikuti prinsip-prinsip yang dapat diterima seperti menepati janji, berperilaku sesuai etika dan jujur. (2) persepsi kebaikan (Benevolence), yang didasarkan pada besarnya kepercayaan kemitraan yang memiliki tujuan dan motivasi yang menjadi kelebihan untuk organisasi lain pada saat kondisi yang baru muncul, yaitu kondisi dimana komitmen tidakterbentuk. (3) persepsi kompetensi (Competence), kompetensi merupakan kemampuan untuk memecahkan permasalahan yang dihadapi oleh konsumen dan memenuhi segala keperluannya. Kemampuan mengacu pada keahlian dan karakteristik yang memungkinkan suatu kelompok mempunyai pengaruh yang dominan.

Produk atau jasa berkualitas mempunyai peranan penting untuk membentuk kepuasan pelanggan (Kotler dan Armstrong, 2001). Semakin berkualitas produk dan jasa yang diberikan, maka kepuasan yang dirasakan oleh pelanggan semakin tinggi. Bila kepuasan pelanggan semakin tinggi, maka dapat menimbulkan keuntungan bagi badan usaha tersebut. Pelanggan yang puas akan terus melakukan pembelian pada badan usaha tersebut. Demikian pula sebaliknya, jika tanpa ada kepuasan, dapat mengakibatkan pelanggan pindah pada produk atau jasa lain. Tingkat kepuasan adalah fungsi dari perbedaan antara kinerja yang dirasakan dengan harapan (Kotler, 2005).

Semakin berkembangnya kemajuan teknologi, internet menjadi hal yang tidak dapat lepas dari manusia. Khususnya di bidang pariwisata. Dalam hal ini adalah tantangan bagi Tourist Information Centre meningkatkan kualitas jasa bagi wisatawan yang berkunjung. Kualitas jasa menjadi acuan para wisatawan dalam mendapatkan kepercayaan dan kepuasan untuk wisatawan. Hal tersebut juga dapat mempengaruhi eksistensi Tourist Information Centre. Adapun kerangka pemikiran yang dibuat oleh penulis untuk memudahkan alur analisis pada penelitian ini:

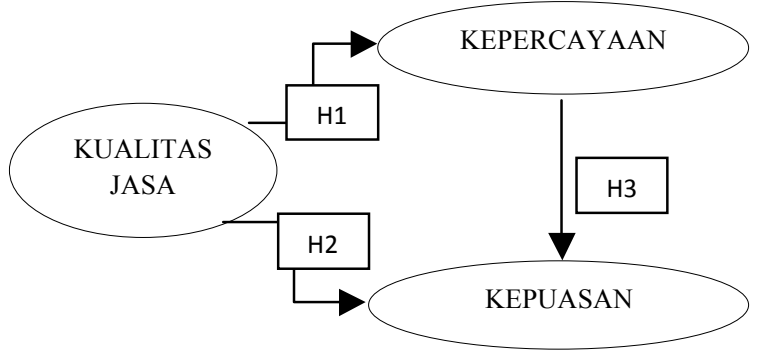

Gambar 1. Kerangka Pemikiran

Sumber : Hasil Penelitian, 2017

Berdasarkan Gambar 1 di atas, dapat diambil hipotesis antara pengaruh masingmasing variabel tersebut di atas adalah sebagai berikut:

H1 : Kualitas Jasa berpengaruh positif dan signifikan terhadap Kepercayaan Wisatawan dalam memperoleh informasi.

H2 : Kualitas Jasa berpengaruh positif dan signifikan terhadap Kepuasan Wisatawan dalam memperoleh informasi.

H3 : Kepercayaan berpengaruh positif dan signifikan terhadap Kepuasan Wisatawan dalam memperoleh informasi.

\section{METODE}

Lokasi penelitian di Tourist Information Centre yang tepatnya berada di Balai Pemuda Kota Surabaya J1. Gubernur Suryo No.15, Kec. Genteng Surabaya. Balai Pemuda menjadi pusat kegiatan masyarakat Surabaya sehingga cukup banyak masyarakat yang berkunjung di sana. Selain itu penelitian tidak hanya berfokus pada Tourist Information Centre saja melainkan pada Dinas Kebudayaan dan Pariwisata Kota Surabaya serta terhadap wisatawan nusantara dan mancanegara yang mengunjungi Tugu Pahlawan dan House of Sampoerna. Kedua destinasi wisata tersebut adalah yang dilewati oleh Surabaya Tourism \& Culinary Track \& Surabaya Heritage Track. Berikut adalah indikator dari kualitas jasa : 
Tabel 2. Definisi Operasional Variabel

\section{Kualitas Jasa}

\begin{tabular}{|c|c|c|}
\hline No & Indikator & Sumber \\
\hline 1 & $\begin{array}{l}\text { Reliabilitas } \\
\text { - Penyampaian informasi } \\
\text { akurat (X.1) } \\
\text { - Informasi yang } \\
\text { disampaikan tepat waktu } \\
\text { (X.2) }\end{array}$ & \\
\hline 2 & $\begin{array}{l}\text { Daya Tanggap } \\
\text { - Kecepatan dalam } \\
\text { menyampaikan informasi } \\
\text { (X.3) } \\
\text { - Penyampaian informasi } \\
\text { dengan baik (X.4) }\end{array}$ & \\
\hline 3 & $\begin{array}{l}\text { Jaminan } \\
\text { - Kesopanan karyawan } \\
\text { (X.5) } \\
\text { - Penguasaan pengetahuan } \\
\text { (X.6) }\end{array}$ & $\begin{array}{c}\text { Parasuraman } \\
\text { (1985) }\end{array}$ \\
\hline 4 & $\begin{array}{l}\text { Empati } \\
\text { - Memahami masalah } \\
\text { wisatawan (X.7) } \\
\text { - Jam operasional yang } \\
\text { nyaman (X.8) }\end{array}$ & \\
\hline 5 & $\begin{array}{l}\text { Bukti Fisik } \\
\text { - Penampilan karyawan } \\
\text { (X.9) } \\
\text { - Adanya brosur / website } \\
\text { (X.10) }\end{array}$ & \\
\hline
\end{tabular}

Sumber : Hasil Penelitian, 2017

Adapun indikator-indikator dari variabel kepercayaan adalah sebagai berikut:

Tabel 3. Definisi Operasional Variabel Kepercayaan

\begin{tabular}{|c|c|c|}
\hline No & Indikator & Sumber \\
\hline 1 & $\begin{array}{l}\text { Integritas (Integrity) } \\
\text { - Informasi sesuai dengan } \\
\quad \text { yang diharapkan }\left(\mathrm{Y}_{1} .1\right)\end{array}$ & \\
\hline 2 & $\begin{array}{l}\text { Kebaikan (Benevolence) } \\
\text { - Penyampaian informasi } \\
\text { meyakinkan }\left(\mathrm{Y}_{1} .2\right)\end{array}$ & Jasfar (2009) \\
\hline 3 & $\begin{array}{l}\text { Kompetensi (Competence) } \\
\text { - Percaya karena jasa resmi } \\
\left(\mathrm{Y}_{1} .3\right)\end{array}$ & \\
\hline
\end{tabular}

Selanjutnya adalah indikator-indikator dari variabel kepuasan adalah sebagai berikut:
Tabel 4. Definisi Operasional Variabel Kepuasan

\begin{tabular}{|c|c|c|}
\hline No & Indikator & Sumber \\
\hline 1 & $\begin{array}{l}\text { Kesesuaian harapan } \\
\text { - Informasi melebihi } \\
\text { dengan yang diharapkan } \\
\left(\mathrm{Y}_{2} .1\right) \\
\text { - Fasilitas penunjang } \\
\text { yang didapat sesuai atau } \\
\text { melebihi dengan yang } \\
\text { diharapkan }\left(\mathrm{Y}_{2} .2\right) \\
\text { - Pelayananan yang } \\
\text { diperoleh sesuai atau } \\
\text { melebihi yang } \\
\text { diharapkan }\left(\mathrm{Y}_{2} .3\right)\end{array}$ & $\begin{array}{l}\text { Hawkins } \\
\text { \&Lonney }\end{array}$ \\
\hline 2 & $\begin{array}{l}\text { Minat berkunjung kembali } \\
\text { - Berminat untuk } \\
\text { mengunjungi kembali } \\
\text { TouristInformation } \\
\text { Centre }\left(\mathrm{Y}_{2} .4\right)\end{array}$ & $\begin{array}{r}\text { dalam } \\
\text { Tjiptono } \\
\text { (2004) }\end{array}$ \\
\hline 3 & $\begin{array}{l}\text { Kesediaan } \\
\text { merekomendasikan } \\
\text { - Merekomendasikan } \\
\text { kepada kerabat untuk } \\
\text { mengunjungi } \\
\text { TouristInformation } \\
\text { Centre }\left(\mathrm{Y}_{2} .5\right)\end{array}$ & \\
\hline
\end{tabular}

Penelitian ini menggunakan kuesioner yang dibagikan kepada wisatawan nusantara maupun mancanegara yang berisi pertanyaanpertanyaan seputar indikator di atas. Kuesioner dibagikan kepada 180 responden. Selain itu untuk mendukung data yang diperlukan, peneliti juga melakukan wawancara terhdap instansi terkait Tourist Information Centre yaitu Dinas Kebudayaan dan Pariwsata Kota Surabaya tepatnya pada bagian pemasaran sebagai pengelola. Teknik analisis yang digunakan dalam penelitian ini adalah menggunakan analisis PLS (Partial Least Square). Metode ini dilakukan dengan cara memaparkan data dari kuisoner yang diperoleh oleh peneliti. Penelitian ini menggunakan analisis statistik berupa uji instrumen yang terdiri dari uji validitas dan uji reliabilitas. Selain itu, dalam kuesioner juga menggunakan Skala Likert adalah skala yang digunakan untuk mengukur persepsi, sikap atau pendapat seseorang atau kelompok mengenai sebuah peristiwa atau fenomena sosial berdasarkan definisi operasional yang telah ditetapkan oleh peneliti (Darmadi, 2011).

Dalam penelitian ini, peneliti menggunakan pertanyaan positif dengan skor: Skor $1=$ Sangat Tidak Setuju 
Skor $2=$ Tidak Setuju

Skor $3=$ Cukup

Skor $4=$ Setuju

Skor $5=$ Sangat Setuju

\section{Analisis PLS (Partial Least Square)}

Partial Least Square (PLS) adalah suatu metode yang berbasis keluarga regresi yang dikenalkan oleh Herman O.A Wold untuk penciptaan dan pembangunan model dan metode untuk ilmu-ilmu sosial dengan pendekatan yang berorientasi pada prediksi. PLS memiliki asumsi data penelitian bebas distribusi, artinya data penelitian tidak mengacuh pada $<$ salah satu distribusi tertentu (misalnya distribusi normal). PLS merupakan metode alternatif dari (SEM) yang dapat digunakan untuk mengatasi permasalahan hubungan diantara variabel yang kompleks namun ukuran sampel datanya kecil (30 sampai 100), mengingat SEM memiliki ukuran sampel data minimal 100.

PLS digunakan untuk mengetahui kompleksitas hubungan suatu konstrak dan konstrak yang lain, serta hubungan suatu konstrak dan indikator-indikatornya. PLS didefinisikan oleh dua persamaan, yaitu inner model dan outer model. Inner model menentukan spesifikasi hubungan antara konstrak dan indikator-indikatornya. Konstrak terbagi menjadi dua yaitu konstrak eksogen dan konstrak endogen. Konstrak eksogen merupakan konstrak penyebab, konstrak yang tidak dipengaruhi oleh konstrak lainnya. Konstrak eksogen memberikan efek kepada konstrak lainnya, sedangkan konstrak endogen merupakan konstrak yang dijelaskan oleh konstrak eksogen. Konstrak endogen adalah efek dari konstrak eksogen (Yamin dan Kurniawan, 2009).

\section{Pengukuran Model (Outer Model)}

Model ini digunakan untuk mengetahui validitas dan reliabilitas yang menghubungkan indikator dengan variabel latennya. Indikator dalam penelitian ini adalah reflektif karena indikator variabel laten mempengaruhi indikatornya, untuk itu digunakan 3 cara pengukuran menurut Sofyan Yamin (2009: 222), yaitu:

1) Convergent Validity

Convergent validity mengukur besarnya korelasi antara konstrak dengan variabel laten. Dalam evaluasi convergent validity dari pemeriksaan individual item realibility, dapat dilihat dari standardized loading factor. Standardize loading factor menggambarkan besarnya korelasi antar setiap item pengukuran (indikator) dengan konstraknya. Kolerasi dapat dikatakan valid apabila memiliki nilai $>0,5$.

2) Discriminant Validity

Evaluasi selanjutnya adalah melihat dan membandingkan antara discriminant validity dan square root of average variance extracted (AVE). Model pengukuran dinilai berdasarkan pengukuran cross loading dengan konstrak. Jika kolerasi konstrak dengan setiap indikatornya lebih besar daripada ukuran konstrak lainnya, maka konstrak laten memprediksi indikatornya lebih baik daripada konstrak lainnya. Jika nilai lebih tinggi daripada nilai kolerasi di antara konstrak, maka discriminant validity yang baik tercapai. Menurut (Tasha Hoover, 2005 dalam Sofyan Yamin, 2009) sangat direkomendasikan apabila AVE lebih besar dari 0,5. Fornnel dan Larcker dalam Ghozali (2005) menyatakan bahwa pengukuran ini dapat digunakan untuk mengukur reliabilitas dan hasilnya konservatif dibandingkan dengan nilai composite reliabity. 3) CompositeReliability

Untuk menentukan compositereliability, apabila nilai compositereliability $>0,8$ dapat dikatakan bahwa konstrak memiliki reliabilitas yang tinggi atau reliable dan > 0,6 dikatakan cukup reliable (Chin, 1998 dalam Sofyan Yamin 2009).

4) Cronbach Alpha

Dalam PLS, uji reliabilitas diperkuat dengan adanya cronbach alpha dimana konsistensi setiap jawaban diujikan. Cronbach alpha di katakan baik apabila $\geq 0,5$ dan dikatakan cukup apabila $\geq 0,3$.

\section{Merancang Model Struktural (Inner Model)}

Model struktural dievaluasi dengan menggunakan $R$-square $\left(\mathrm{R}^{2}\right)$ untuk konstrak dependen, Stone-Geisser Q-squaretest untuk predictive relevane dan uji $\mathrm{t}$ serta dari koefisien parameter jalur structural. $\mathrm{R}^{2}$ dapat digunakan untuk menilai variabel laten independen terhadap variabel laten dependen apakah mempunyai pengaruh yang substantive. Kriteria batasan nilai $\mathrm{R}^{2}$ ini dalam tiga klasifikasi, yaitu 0,67, 0,33, dan 0,19. Disamping melihat nilai R-square, model PLS juga dievaluasi dengan melihat $Q$-square 
predictive relevance untuk mengukur sebeapa baik nilai observasi dihasilkan oleh model dan juga estimasi parameternya. Nilai Q-square lebih besar dari 0 (nol) menunjukan bahwa model mempunyai nilai predictive relevance, sedangkan nilai $Q$-square kurang dari 0 (nol) menunjukan bahwa model kurang memiliki predictive relevance.

\section{HASIL DAN PEMBAHASAN}

Tourist Information Centre adalah suatu fasilitas penyedia informasi kepariwisataan yang resmi dikelola oleh Dinas Kebudayaan dan Pariwisata Kota Surabaya yang terletak di Balai Pemuda Kota Surabaya. Tourist Information Centre ini diharapkan dapat membantu wisatawan dalam memperoleh informasi seputar Kota Surabaya maupun sekitarnya. Berikut adalah informasi umum mengenai Tourist Information Centre di Kota Surabaya:

Alamat : Balai Pemuda, JL. Gubernur Suryo No.15 Surabaya

Telepon : $031-5340444$

Email : tic_surabaya@yahoo.com

Twitter : @TICSby

Website :http://sparkling.surabaya.go.id

Facebook : Surabaya Tourism Information Center

Jika berkunjung ke Tourist Information Centre bisa kita lihat banyak sekali brosur kepariwsataan maupun majalah seputar Kota Surabaya. Selain itu, disana juga menjual beberapa produk kerajinan tangan dari UMKM Kota Surabaya seperti dompet, tas, gantungan kunci, hiasan dinding dan masih banyak lagi kerajinan tangan yang melambangkan Kota Surabaya untuk dijadikan sebagai oleh-oleh khas Kota Surabaya. Bagi wisatawan yang berkunjung ke Balai Pemuda Kota Surabaya pasti melihat satu bus unik yang bertuliskan "Sparkling Surabaya". Bus tersebut adalah milik pemerintah Kota Surabaya yang dikelola Dinas Kebudayaan dan Pariwisata Kota Surabaya sebagai upaya meningkatkan kunjungan wisatawan dan dapat lebih mengenal destinasi wisata di Kota Surabaya beserta sejarahnya. Dalam mengkemas produk wisata tersebut, pemerintah mencetuskan suatu program yaitu "Surabaya Shopping and Culinary Track" dengan menggunakan bus tersebut. Masyarakat maupun wisatawan bisa membeli tiket di Tourist Information Centre dengan harga yang cukup terjangkau yaitu $\mathrm{Rp}$ 7.500 rupiah / orang. Setiap hari Selasa, Sabtu, Minggu pukul $09.00-14.00(+/-5$ jam perjalanan).

Berdasarkan hasil wawancara dengan Kepala Bidang Promosi Dinas Kebudayaan dan Pariwisata Kota Surabaya dengan Bapak Wahyudi mengatakan bahwa tidak ada struktur organisasi yang spesifik untuk Tourist Information Centre. Maka dalam hal ini peneliti memasukkan beberapa petugas yang bekerja pada Tourist Information Centre sebagai berikut: 1. Sultan Firstarizki Huda, 2) Karina Rachmawati, 3) Mahardhika August S.

Pentingnya pelayanan dalam suatu perusahaan jasa juga perlu untuk memberikan pelayanan terbaik kepada konsumen. Berikut adalah pelayanan yang diberikan oleh Tourist Information Centre:

a) Mengucapkan salam dan kalimat menawarkan bantuan (Salam, Senyum Sapa)

b) Menjelaskan obyek wisata yang ada di Surabaya. Selain itu juga dapat memberikan informasi lain seputar kepariwisataan di Kota Surabaya.

c) Jika wisatawan bertanya tentang informasi luar Surabaya, dapat dijelaskan secara umum.

\section{Analisis PLS (Partial Least Square)}

Teknik pengolahan data dengan menggunakan metode SEM berbasis Partial Least Square (PLS). Software PLS pada penelitian ini menggunakan software yang dikembangkan di University of Hamburg Jerman yang diberi nama SMARTPLS versi $2.0 \mathrm{M} 3$. 


\section{Evaluasi Model Pengukuran/ Measurement (Outer Model)}

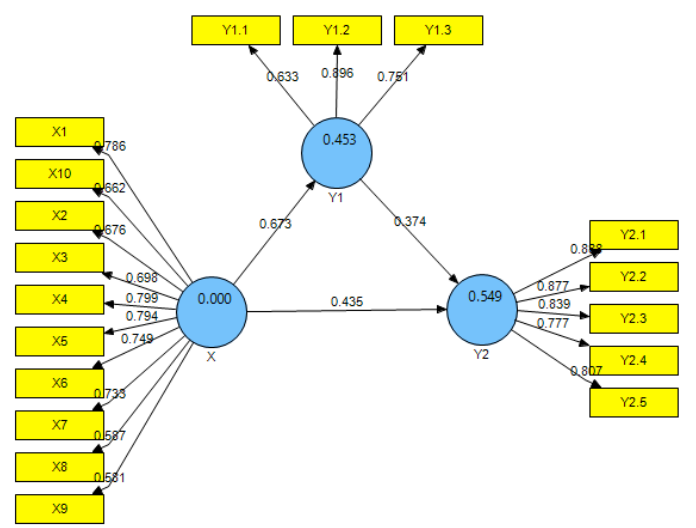

Gambar 2. Model Struktural (Outer Model)

Terdapat tiga kriteria di dalam penggunaan teknik analisa data dengan Smart PLS untuk menilai outer model yaitu Convergent Validity, Discriminant Validity dan Composite Reliability.

\section{Convergent Validity}

Validitas konvergen bertujuan untuk mengetahui validitas setiap hubungan antara indikator dengan variabel latennya. Nilai loadingfactor di atas 0,7 dikatakan ideal dan valid. Tetapi, nilai loadingfactor di atas 0,5 juga masih dapat diterima asalkan nilainya tidak dibawah 0,5. Berikut disajikan hasil dari outerloading untuk setiap indikator-indikator yang dimiliki oleh tiap-tiap variabel:

Tabel 5. OuterLoadings (Mean, STDEV, t-Values)

\begin{tabular}{ccrc}
\hline & $\begin{array}{c}\text { Original } \\
\text { Sample } \\
(\mathrm{O})\end{array}$ & $\begin{array}{c}\text { Standard } \\
\text { Deviation } \\
(\text { STDEV })\end{array}$ & $\begin{array}{c}\text { 作 } \\
\text { Statistics } \\
(\mid \mathrm{O} / \mathrm{STE} \\
\mathrm{RR} \mid)\end{array}$ \\
$\mathrm{X} 1$ & 0.7864 & 0.0292 & 26.9671 \\
$\mathrm{X} 2$ & 0.6762 & 0.0395 & 17.1089 \\
$\mathrm{X} 3$ & 0.6983 & 0.0435 & 16.0364 \\
$\mathrm{X} 4$ & 0.7989 & 0.0232 & 34.5049 \\
$\mathrm{X} 5$ & 0.7937 & 0.0269 & 29.5209 \\
$\mathrm{X} 6$ & 0.7488 & 0.0307 & 24.4245 \\
$\mathrm{X} 7$ & 0.733 & 0.0392 & 18.686 \\
$\mathrm{X} 8$ & 0.5874 & 0.058 & 10.1353 \\
$\mathrm{X} 9$ & 0.581 & 0.0621 & 9.3537 \\
$\mathrm{X} 10$ & 0.6617 & 0.051 & 12.9825 \\
$\mathrm{Y} 1.1$ & 0.6331 & 0.0791 & 7.9994 \\
$\mathrm{Y} 1.2$ & 0.896 & 0.016 & 56.0326 \\
\hline
\end{tabular}

\begin{tabular}{llll} 
Y1.3 & 0.7507 & 0.0548 & 13.6989 \\
Y2.1 & 0.8883 & 0.0166 & 53.4885 \\
Y2.2 & 0.8771 & 0.0179 & 48.9831 \\
Y2.3 & 0.8387 & 0.0303 & 27.6756 \\
Y2.4 & 0.7769 & 0.0354 & 21.9461 \\
Y2.5 & 0.8069 & 0.0262 & 30.7711 \\
\hline
\end{tabular}

Sumber : Hasil Penelitian, 2017

\section{Discriminant Validity}

Discriminant Validity adalah untuk membuktikan bahwa konstruk laten memprediksi ukuran pada blok mereka lebih baik daripada ukuran pada blok lainnya. Ghozali (2008) menyebutkan bahwa discriminant validity dari model pengukuran dengan refleksif indikator dinilai berdasarkan cross loading pengukuran dengan konstruk. Discriminant validity dari model pengukuran dinilai berdasarkan pengukuran cross loading dengan konstruk. Jika korelasi konstruk dengan pokok pengukuran (setiap indikatornya) lebih besar daripada ukuran konstruk lainnya, maka konstruk laten memprediksi indikatornya lebih baik daripada konstruk lainnya.

Tabel 6. Nilai Cross Loading

\begin{tabular}{lrrr}
\hline Item & \multicolumn{1}{c}{ X } & \multicolumn{1}{c}{ Y1 } & \multicolumn{1}{c}{ Y2 } \\
X1 & $\mathbf{0 . 7 8 6 4}$ & 0.514 & 0.5496 \\
X2 & $\mathbf{0 . 6 7 6 2}$ & 0.4238 & 0.4557 \\
X3 & $\mathbf{0 . 6 9 8 3}$ & 0.431 & 0.4453 \\
X4 & $\mathbf{0 . 7 9 8 9}$ & 0.5268 & 0.558 \\
X5 & $\mathbf{0 . 7 9 3 7}$ & 0.5302 & 0.5527 \\
X6 & $\mathbf{0 . 7 4 8 8}$ & 0.498 & 0.5115 \\
X7 & $\mathbf{0 . 7 3 3}$ & 0.5125 & 0.5137 \\
X8 & $\mathbf{0 . 5 8 7 4}$ & 0.3566 & 0.3389 \\
X9 & $\mathbf{0 . 5 8 1}$ & 0.4495 & 0.3387 \\
X10 & $\mathbf{0 . 6 6 1 7}$ & 0.5055 & 0.5459 \\
Y1.1 & 0.4856 & $\mathbf{0 . 6 3 3 1}$ & 0.3661 \\
Y1.2 & 0.627 & $\mathbf{0 . 8 9 6}$ & 0.6422 \\
Y1.3 & 0.4168 & $\mathbf{0 . 7 5 0 7}$ & 0.4919 \\
Y2.1 & 0.6162 & 0.6114 & $\mathbf{0 . 8 8 8 3}$ \\
Y2.2 & 0.5934 & 0.5928 & $\mathbf{0 . 8 7 7 1}$ \\
Y2.3 & 0.5679 & 0.5246 & $\mathbf{0 . 8 3 8 7}$ \\
Y2.4 & 0.5393 & 0.5106 & $\mathbf{0 . 7 7 6 9}$ \\
Y2.5 & 0.561 & 0.5515 & $\mathbf{0 . 8 0 6 9}$
\end{tabular}

Sumber : Hasil Penelitian, 2017

Berdasarkan nilai cross loading, dapat diketahui bahwa semua indikator yang menyusun masing-masing variabel dalam penelitian ini (nilai yang dicetak tebal) telah memenuhi discriminant validity karena 
memiliki nilai outer loading terbesar untuk variabel yang dibentuknya dan tidak pada variabel yang lain. Dengan demikian semua indikator di tiap variabel dalam penelitian ini telah memenuhi discriminant validity.

\section{Composite Reliability}

Evaluasi model pengukuran dengan square root of average variance extracted adalah membandingkan nilai akar AVE dengan korelasi antar konstruk. Jika nilai akar AVE lebih tinggi daripada nilai korelasi di antara konstruk, maka discriminant validity yang baik tercapai. Selain itu, nilai AVE lebih besar dari 0,5 sangat direkomendasikan. Konstruk dinyatakan reliabel jika nilai composite reliability maupun nilai cronbach alpha di atas 0,70. Berikut hasil output composite reliability dan cronbach alpha:

Tabel 7. Goodnessof Fit

\begin{tabular}{lrrr} 
Variabel & AVE & $\begin{array}{r}\text { Composite } \\
\text { Reliability }\end{array}$ & $\begin{array}{c}\text { Cronbach } \\
\text { Alpha }\end{array}$ \\
$\mathrm{X}$ & 0.505 & 0.9098 & 0.8892 \\
$\mathrm{Y} 1$ & 0.589 & 0.8083 & 0.6412 \\
& 1 & & \\
$\mathrm{Y} 2$ & 0.703 & 0.922 & 0.8938 \\
& 3 & & \\
\hline
\end{tabular}

Sumber : Hasil Penelitian, 2017

Nilai AVE untuk keempat konstruk tersebut lebih besar dari 0,5 sehingga dapat disimpulkan bahwa evaluasi pengukuran model memiliki discriminant validity yang baik. Disamping uji validitas konstruk, dilakukan juga uji reliabilitas konstruk yang diukur dengan uji criteria yaitu compositereliability dan cronbachalpha dari blok indikator yang mengukur konstruk. Konstruk yang dinyatakan reliable jika nilai composite reliability maupun cronbach alpha di atas 0.70. Jadi dapat disimpulkan bahwa konstruk memiliki reliabilitas yang baik.

\section{Evaluasi Model Struktural / Structural (Inner Model)}

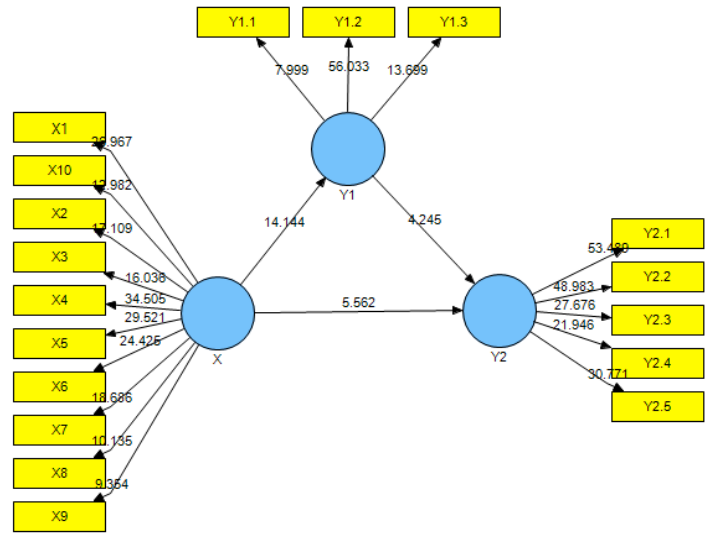

Gambar 3. Model Struktural (Inner Model)

Pengujian inner model atau model struktural dilakukan untuk melihat hubungan antara konstruk nilai signifikansi dan R-square dari model penelitian. Model struktural dievaluasi dengan menggunakan $\mathrm{R}$-square untuk konstruk dependen uji $t$ serta signifikansi dari koefisien parameter jalur struktural.

\section{R-Square $\left(\mathbf{R}^{2}\right)$}

Pengujian terhadap model struktural dilakukan dengan melihat nilai $R$-square yang merupakan uji goodness-fit model.

Tabel 8 Nilai R-Square

\begin{tabular}{cc}
\hline Variabel & R Square \\
Y1 & 0.4534 \\
Y2 & 0.5487 \\
\hline \multicolumn{2}{c}{ Sumber : Hasil Penelitian, 2017 }
\end{tabular}

Nilai R-square tersebut menunjukkan bahwa 45,34\% variabel Kepercayaan (Y1) dapat dipengaruhi oleh variabel Kualitas Jasa (X). sedangkan sisanya $54,66 \%$ di pengaruhi oleh variabel lain di luar yang diteliti.

Nilai R-square Kepuasan sebesar 0,5487 menunjukkan variabel Kepuasan (Y2) dipengaruhi oleh variabel Kualitas Jasa (X), dan Kepercayaan (Y1) sebesar 54,87\% sedangkan sisanya $45,13 \%$ di pengaruhi oleh variabel lain di luar yang diteliti. 


\section{Predictive Relevance $\left(Q^{2}\right)$}

$Q$-Square predictive relevance untuk model struktural, megukur seberapa baik nilai konservasi dihasilkan oleh model dan juga estimasi parameternya. Besaran $\mathrm{Q}^{2}$ memiliki nilai dengan rentang $0<\mathrm{Q}^{2}<1$, dimana semakin mendekati 1 berarti model semakin baik. Besaran $\mathrm{Q}^{2}$ ini setara dengan koefisien determinasi total pada analisis jalur (path analysis).

Berdasarkan tabel 8 maka perhitungan predictive relevance adalah sebagai berikut:

$$
\begin{aligned}
\text { Nilai } Q^{2} & =1-\left(1-\mathrm{R}_{1}{ }^{2}\right) \times\left(1-\mathrm{R}_{2}{ }^{2}\right) \\
\text { Nilai } Q^{2} & =1-(1-0.4534) \times(1- \\
& 0.5487) \\
= & 0.7533
\end{aligned}
$$

Keterangan:

Q2 : nilai Predictive Relevance

$\mathrm{R}_{1}{ }^{2}$ : nilai $R$-Square variabel

Kepercayaan

$\mathrm{R}_{2}{ }^{2} \quad$ : nilai $R$-Square variabel Kepuasan

Dari hasil perhitungan tersebut diketahui nilai $\mathrm{Q}^{2}$ sebesar 0.7533 , artinya adalah besarnya keragaman data dari penelitian yang dapat dijelaskan oleh model struktural yang dirancang adalah sebesar $75,33 \%$, sedangkan sisanya $24,67 \%$ dijelaskan oleh faktor lain diluar model. Berdasarkan hasil ini dapat dikatan model struktural pada penelitian ini cukup baik karena lebih mendekati nilai 1 .

\section{Pengujian Hipotesis Penelitian}

Signifikansi parameter yang diestimasi memberikan informasi yang sangat berguna mengenai hubungan antara variabel-variabel penelitian. Dalam PLS pengujian secara statistik setiap hubungan yang dihipotesiskan dilakukan dengan menggunakan simulasi. Dalam hal ini dilakukan metode bootstrap terhadap sampel. Pengujian dengan bootstrap juga dimaksudkan untuk meminimalkan masalah ketidaknormalan data penelitian. Hasil pengujian dengan bootstrapping dari analisis PLS adalah sebagai berikut:
Tabel 9. PathCoefficient (Mean, STDEV, T-Values)

\begin{tabular}{lcrr}
$\begin{array}{c}\text { Variabel } \\
\text { Bebas }\end{array}$ & $\begin{array}{c}\text { Original } \\
\text { Sample } \\
(\mathrm{O})\end{array}$ & $\begin{array}{c}\text { Standard } \\
\text { Deviation } \\
\text { (STDEV) }\end{array}$ & $\begin{array}{c}\text { T Statistics } \\
(|\mathrm{O} / \mathrm{STERR}|)\end{array}$ \\
$\mathrm{X} \mathrm{->} \mathrm{Y1}$ & 0.6733 & 0.0476 & 14.1439 \\
$\mathrm{X} \mathrm{->} \mathrm{Y2}$ & 0.4351 & 0.0782 & 5.5616 \\
Y1 -> & 0.3743 & 0.0882 & 4.2447 \\
Y2 & & & \\
\hline
\end{tabular}

Sumber : Hasil Penelitian, 2017

Persamaan struktural yang didapat adalah :

$\mathrm{Y} 1=0,6733 \mathrm{X}$

$\mathrm{Y} 2=0,4351 \mathrm{X}+0,3743 \mathrm{Y}$

Signifikansi parameter yang diestimasi memberikan informasi yang sangat berguna mengenai hubungan antara variabel-variabel penelitian.

\section{Pengaruh Kualitas Jasa terhadap Kepercayaan}

Kualitas Jasa mempunyai pengaruh positif secara langsung dan signifikan terhadap Kepercayaan. Nilai variabel Kualitas Jasa terhadap Kepercayaan dengan koefisien jalur sebesar 0,6733 dan t statistik sebesar 14,1439. nilai tersebut lebih besar dari t tabel $(1,960)$ atau $\mathrm{p} \leq 0,05 \%$. Sehingga kualitas jasa memberikan pengaruh yang signifikan terhadap Kepercayaan. Dari hasil diatas menunjukkan bahwa $\mathrm{H} 0$ ditolak dan $\mathrm{H} 1$ diterima hal ini berarti hipotesis pertama diterima. Hasil tersebut di atas juga didukung oleh hasil penelitian Molden Elrado $\mathrm{H}$, dkk (2014) menunjukkan bahwa variabel kualitas pelayanan yang terdiri dari lima indikator yaitu bukti fisik, kehandalan, daya tanggap, jaminan dan empati berpengaruh terhadap kepercayaan pelanggan. Hasil penelitian ini juga mendukung penelitian yang dilakukan oleh Rahmadaniaty (2012) yang menyatakan bahwa terdapat pengaruh signifikan antara mutu pelayanan dan kepercayaan pelanggan. Adanya kualitas pelayanan yang baik maka dapat menciptakan kepercayaan di benak pelanggan bahwa pelayanan yang diberikan adalah baik.

\section{Pengaruh Kualitas Jasa terhadap Kepuasan}

Kualitas Jasa mempunyai pengaruh positif secara langsung dan signifikan terhadap Kepuasan. Nilai variabel Kualitas Jasa 
terhadap Kepuasan dengan koefisien jalur sebesar 0,4351 dan t statistik sebesar 5,5616 nilai tersebut lebih besar dari t tabel $(1,960)$ atau $\mathrm{p} \leq 0,05 \%$. Sehingga kualitas jasa memberikan pengaruhn yang signifikan terhadap Kepuasan. Dari hasil diatas menunjukkan bahwa $\mathrm{H} 0$ ditolak dan $\mathrm{H} 1$ diterima hal ini berarti hipotesis kedua diterima. Hasil yang didapat juga dapat diperkuat dengan hasil penelitian milik Ratih Hardiyati (2010) yang menunjukkan bahwa setiap indikator pada variabel kualitas jasa berpengaruh positif dan signifikan terhadap kepuasan. Hasil penelitian ini juga mendukung penelitian yang dilakukan oleh Sugiyati dan Kusnilawati (2013) yang menyatakan bahwa kualitas pelayanan mempunyai pengaruh yang signifikan terhadap kepuasan pelanggan. Dengan demikian dapat disimpulkan bahwa dengan adanya kualitas pelayanan yang baik dapat menciptakan kepuasan pelanggan yang menggunakan jasa tersebut sehingga pelanggan tidak kecewa.

\section{Pengaruh Kepercayaan terhadap Kepuasan}

Kepercayaan mempunyai pengaruh positif secara langsung dan signifikan terhadap Kepuasan. Nilai variabel Kepercayaan terhadap Kepuasan dengan koefisien jalur sebesar 0,3743 dan t statistik sebesar 4,2447 nilai tersebut lebih besar dari $\mathrm{t}$ tabel $(1,960)$ atau $\mathrm{p} \leq 0,05 \%$. Sehingga kepercayaan memberikan pengaruh yang signifikan terhadap kepuasan. Dari hasil diatas menunjukkan bahwa $\mathrm{H} 0$ ditolak dan $\mathrm{H} 1$ diterima hal ini berarti hipotesis ketiga diterima. Sama halnya dengan penelitian milik Okky Erviana (2013) yang memperkuat dengan hasil penelitian variabel kepercayaan berpengaruh positif terhadap kepuasan pasien rawat inap secara signifikan. Terciptanya kepercayaan merupakan salah satu keberhasilan proses pemasaran, karena pada dasarnya kepercayaan yang baik dapat dianggap sebagai pengakuan dan penghargaan dari konsumen terhadap kegunaan produk atau jasa yang diberikan oleh penyedia layanan yang sesuai dengan harapan pelanggan.

Adapun hasil tersebut mendukung penelitian milik Irfan ListyonoRaharjo (2015) dengan hasil penelitian menunjukkan bahwa terdapat pengaruh yang positif dan signifikan antara kepercayaan terhadap kepuasan pelanggan, artinya apabila Kepercayaan pelanggan ditingkatkan maka kepuasan pelanggan akan meningkat.

\section{Pengujian Kepercayaan sebagai Variabel Intervening dalam Hubungan Kualitas Jasa terhadap Kepuasan}

Pada hubungan Kualitas Jasa dengan Kepuasan terdapat dugaan variabel kepercayaan sebagai variabel intervening. Perhitungan besarnya pengaruh kepercayaan sebagai variabel intervening adalah sebagai berikut :

Direct Effect (pengaruh langsung) Kualitas Jasa terhadap Kepuasan sebesar 0,4351

$$
\begin{aligned}
& \text { Indirect Effect }(\mathrm{IE})=\left(\mathrm{PY}_{1} \mathrm{X}\right) \times\left(\mathrm{PY}_{2} \mathrm{Y}_{1}\right) \\
& =0,6733 \times(0,3743) \\
& =0,252 \\
& \begin{aligned}
\text { Total Effect }(\mathrm{TE}) & =\mathrm{PZX}+\left(\mathrm{PYX} \times \mathrm{PY}_{2} \mathrm{Y}_{1}\right) \\
= & 0,4351+0,252 \\
= & 0,6871
\end{aligned}
\end{aligned}
$$

\begin{tabular}{|c|c|c|c|c|c|c|c|}
\hline $\begin{array}{c}\text { Varia } \\
\text { bel }\end{array}$ & \multicolumn{2}{|c|}{$\begin{array}{l}\text { Koefisien } \\
\text { Langsung }\end{array}$} & \multicolumn{2}{|c|}{ standar error } & $\begin{array}{l}\text { Koefi } \\
\text { sien }\end{array}$ & $\begin{array}{c}\mathrm{seG} \\
\mathrm{ab}\end{array}$ & $\begin{array}{c}\mathrm{t} \\
\text { Hitung }\end{array}$ \\
\hline $\begin{array}{l}X, Y_{1}, \\
Y_{2}\end{array}$ & 0.6733 & $\begin{array}{r}0.37 \\
43\end{array}$ & $\begin{array}{r}0.04 \\
76\end{array}$ & $\begin{array}{r}0.08 \\
82\end{array}$ & 0.252 & $\begin{array}{r}0.06 \\
21\end{array}$ & $\begin{array}{r}4.05 \\
5\end{array}$ \\
\hline
\end{tabular}

Tabel 10. Rekapitulasi Pengaruh Langsung, Tidak Langsung, dan Pengaruh Total

Sumber : Hasil Penelitian, 2017

Dari hasil perhitungan tersebut menunjukkan bahwa kepercayaan terbukti sebagai variabel intervening dalam hubungan antara kualitas jasa dengan kepuasan. Hal ini dibuktikan dengan hasil perhitungan Indirect Effect yang bernilai 0,252. Total pengaruh (Total Effect) kualitas jasa terhadap kepuasan melalui kepercayaan sebesar 0,6873. Hal ini menunjukkan bahwa semakin membaiknya kepercayaan akan menjadi jembatan yang baik bagi hubungan antara kualitas jasa dengan kepuasan.

Hasil yang didapat pada penelitian ini didukung oleh hasil penelitian milik Gunarto Heru Santoso (2011) yang menjadikan kepercayan sebagai variabel intervening antara kualitas pelayanan dan kepuasan. Kepercayaan nasabah mampu memediasi pengaruh tangibles, reliability, responsiveness, assurance dan emphaty terhadap kepuasan nasabah sehingga pengaruh tangibles, reliability, responsiveness, assurance dan emphaty terhadap kepuasan nasabah dapat melalui kepercayaan nasabah. 


\section{SIMPULAN DAN SARAN \\ Simpulan}

Berdasarkan hasil dan pembahasan diatas, dapat disimpulkan bahwa Kota Surabaya memiliki 1 Tourist Information Centre yang diadakan untuk menunjang kegiatan kepariwisataan di Kota Surabaya. Namun terjadi penurunan jumlah kunjungan yang membuat penulis ingin mengidentifikasi hal ini.

Permasalahan yang telah dirumuskan, hasil analisis dan pengujian hipotesis yang telah dilakukan pada bab sebelumnya, maka dari penelitian yang dilakukan dapat diambil kesimpulan hasil penelitian menunjukan bahwa variabel kualitas jasa (x) memiliki pengaruh secara langsung terhadap kepercayaan (y1). Kemdian hasil penelitian menunjukan bahwa variabel kualitas jasa (x) berpengaruh positif terhadap kepuasan (y2), hasil penelitian menunjukan bahwa variabel kepercayaan (y1) berpengaruh positif terhadap kepuasan (y2). Serta hasil penelitian menunjukkan bahwa variabel kepercayaan menjadi variabel intervening antara variabel kualitas jasa dan kepuasan. Selain dari simpulan berdasarkan rumusan masalah, terdapat pula simpulan berdasarkan observasi lapangan bahwa wisatawan enggan untuk datang ke Tourist Information Centre dikarenakan lebih memilih mengakses informasi melalui internet.

\section{Saran}

Diharapkan pihak instansi dapat mempertahankan serta meningkatkan pelayanan terhadap kualitas jasa, karena variabel kualitas jasa mempunyai pengaruh yang signifikan terhadap kepercayaan dan kepuasan, diantaranya yaitu dengan memperlama jam operasional agar wisatawan lebih fleksibel untuk mendapatkan informasi. Selain itu perlu ditambahkan berbagai fasilitas supaya dapat menarik wisatawan agar dapat berkunjung kembali ke Tourist Information Centre.

Mengingat kualitas jasa dalam penelitian ini merupakan hal yang sangat penting dalam mempengaruhi kepuasan diharapkan hasil penelitian ini dapat dipakai sebagai acuan bagi peneliti selanjutnya untuk mengembangkan penelitian ini dengan mempertimbangkan variabel-variabel lain yang merupakan variabel lain diluar variabel yang sudah masuk dalam penelitian ini.

Untuk kedepannya bisa dibuat Tourist Information Centre yang berbasis online. Untuk mengikuti perkembangan zaman dimana wisatawan lebih mengandalkan internet. Selain itu, diharapkan untuk membenahi lokasi Tourist Information Centre agar lebih menarik dan terlihat oleh wisatawan. 


\section{Kepustakaan}

A. Parasuraman, Valerie A. Zeithaml, Leonard Berry. 1985. A Conceptual Model of Service QualityandItsImplicationfor Future Research. Journal of Marketing .Vol.49.

A.Popoola, Babatunde, Richard Chinomona, Elizabeth Chinomona. 2014. The Influence of In formation Quality on Student's Self Efficacy at Instutions of Higher Learning in South Africa. Mediterranean Journal of Social Sciences.Vol. 5.

A. Yoeti. Oka. 1992. Pengantar Ilmu Pariwisata. Bandung : Angkasa.

Al-Ababneh, Mukhles. 2013. Service Qualityandit's Impacton Tourist Satisfaction. Interdiscplinary Journalof Contemporary Research in Business.Vol.4

Anonim. Undang-Undang Republik Indonesia No. $10 \quad$ Th. 2009 tentang Kepariwisataan.

Anonim. Peraturan Daerah Kota Surabaya No.23 Th. 2012.

Ba, S., and Pavlou, P.A. 2002. Evidenceof The Effectof Trust Building Technology in Electronic Markets: Price Premium andBuyerBehavior. MIS Quarterly.

Darmadi, Hamid. 2011 MetodePenelitianPendidikan. Bandung: Alfabeta.

Elrado, Molden, Srikadi, Edy. 2014. Pengaruh Kualitas Pelayanan terhadap Kepuasan, Kepercayaan dan Loyalitas Pelanggan yang Menginap di jambuluwuk Resort Kota Batu. Jurnal Administrasi Bisnis.Vol. 15.

Erviana, Okky. 2013. Pengaruh Kualitas Pelayanan dan Kepercayaan terhadap Kepuasan Pasien Rawat Inap di RSUD Dr. Soewono Kendal.
Hermano, Arieman. 2010. Analisis Pengaruh Kualitas Layanan, Kepercayaan dan Kepuasan Terhadap Pelanggan pada PT. Kharisma Gamaba Jaya Surabaya.

Ghozali, I., 2005. Aplikasi Analisis Multivariate Dengan Program Spss. Semarang: Universitas Diponegoro.

Hardiyati, Ratih. 2010. Analisis Pengaruh Kualitas Pelayanan Terhadap Kepuasan Konsumen Menggunakan Jasa Penginapan (Villa) Agrowisata Kebun Teh Pagilaran.

Pramana, I Gede Yogi, Ni Made Rastini. Pengaruh Kualitas Pelayanan Terhadap Kepercayaan Nasabah dan Loyalitas Bank Mandiri. E-Journal Manajemen Unud. Vol. 5.

Heru, Gunarto Santoso. 2011. Analisis Pengaruh Kualitas Pelayanan Terhadap Kepuasan Nasabah Dengan Kepercayaan Sebagai Variabel Intervening Pada PT. Bank Rakyat Indonesia (Persero) Tbk. Kantor Cabang Wonogiri.

Jasfar, F. 2009. Manajemen Jasa Pendekatan Terpadu. Jakarta : Ghalia Indonesia.

Kotler, Amstrong. 2001. Prinsip-Prinsip Pemasaran. Edisi keduabelas Jilid 1. Jakarta: Erlangga

2005. Manajamen Pemasaran, Jilid 1 dan 2. Jakarta PT. Indeks : Kelompok Gramedia.

Listyono, Irfan. 2015. Analisis Pengaruh Harga, Kepercayaan Pelanggan, dan Kualitas Pelayanan Terhadap Loyalitas Pelanggan Melalui Kepuasan Pelanggan Pada J.CoDonuts\& Coffee Java Mall.

Rahmadaniati, Masniari dan Arnita. 2012. Penerapan Metode StructuralEquation Modeling (SEM) Dalam Menentukan Pengaruh Kepuasan, Kepercayaan Dan Mutu Terhadap Kesetiaan Pasien Rawat Jalan Dalam Memanfaatkan Pelayanan Rumah Sakit. Jurnal USU, 2013 Vol 2. 
Sugiyati, Kusnilawati. 2013. Pengaruh Kualitas Pelayanan Jasa Dan Kepercayaan Terhadap Loyalitas Pelanggan Dengan Kepuasan Pelanggan Sebagai Variabel Intervening. Dinamika Manajemen, Juli 2013 Vol. 3.

Suardana, I Wayan. 2015. An Examination Of The Relationship Among Motivation, Satisfaction, Treust, And Product Loyalty. I J A B E R, Vol. 13, No.5.

Tjiptono, Fandy. 2004. Strategi Pemasaran Edisi Kedua. Jakarta : Andi.

Yamin, Sofyan \& Heri Kurniawan. 2009. Structural Equation Modelling: lebih mudah mengolah data kuesioner dengan Lisrel dansmartPLS. Salemba Infotek : Jakarta. 